\title{
Diagnostic accuracy of spot urine protein-to- creatinine ratio for proteinuria and its association with adverse pregnancy outcomes in Chinese pregnant patients with pre-eclampsia
}

\author{
HC Cheung *, KY Leung, CH Choi
}

This article was published on 6 May 2016 at www.hkmj.org.

\section{A B S T R A C T}

Introduction: International guidelines have endorsed spot urine protein-to-creatinine ratio of $>30 \mathrm{mg}$ protein $/ \mathrm{mmol}$ creatinine as an alternative to a 24-hour urine sample to represent significant proteinuria. This study aimed to determine the accuracy of spot urine protein-to-creatinine ratio in predicting significant proteinuria and adverse pregnancy outcome.

Methods: This case series was conducted in a regional obstetric unit in Hong Kong. A total of 120 Chinese pregnant patients with pre-eclampsia delivered at Queen Elizabeth Hospital from January 2011 to December 2013 were included. Relationship of spot urine protein-to-creatinine ratio and 24-hour proteinuria; accuracy of the ratio against 24-hour urine protein at different cut-offs; and relationship of such ratio and adverse pregnancy outcome were studied.

Results: Spot urine protein-to-creatinine ratio was correlated with 24-hour urine protein with Pearson correlation coefficient of $0.914(\mathrm{P}<0.0001)$ when the ratio was $<200 \mathrm{mg} / \mathrm{mmol}$. The optimal threshold of spot urine protein-to-creatinine ratio for diagnosing proteinuria in Chinese pregnant patients (33 $\mathrm{mg} / \mathrm{mmol}$ ) was similar to that stated in the international literature $(30 \mathrm{mg} / \mathrm{mmol})$. A cut-off of $20 \mathrm{mg} / \mathrm{mmol}$ provided a $100 \%$ sensitivity, and 52 $\mathrm{mg} / \mathrm{mmol}$ provided a $100 \%$ specificity. There was no significant difference in spot urine protein-tocreatinine ratio between cases with and without adverse pregnancy outcome.

Conclusions: Spot urine protein-to-creatinine ratio had a positive and significant correlation with 24-hour urine results in Chinese pre-eclamptic women when the ratio was $<200 \mathrm{mg} / \mathrm{mmol}$. Nonetheless, this ratio was not predictive of adverse pregnancy outcome.

\section{Hong Kong Med J 2016;22:249-55}

DOI: $10.12809 / \mathrm{hkmj} 154659$

\author{
${ }^{1} \mathrm{HC}$ Cheung *, MB, BS, MRCOG \\ ${ }^{1}$ KY Leung, FRCOG, FHKAM (Obstetrics and Gynaecology) \\ ${ }^{2} \mathrm{CH}$ Choi, FHKCP, FHKAM (Medicine) \\ ${ }^{1}$ Department of Obstetrics and Gynaecology \\ Department of Medicine \\ Queen Elizabeth Hospital, Jordan, Hong Kong \\ * Corresponding author: chc670@ha.org.hk
}

New knowledge added by this study

- Spot urine protein-to-creatinine ratio (uPCR) had a positive and significant correlation with 24-hour urine results in Chinese pre-eclamptic women when uPCR was $<200 \mathrm{mg} / \mathrm{mmol}$.

- uPCR was not predictive of adverse pregnancy outcome in Chinese pre-eclamptic women.

Implications for clinical practice or policy

- The optimal threshold for diagnosis of proteinuria in the local Chinese population was similar to the $30 \mathrm{mg} / \mathrm{mmol}$ suggested by international guidelines.

- When uPCR is $<20 \mathrm{mg} / \mathrm{mmol}$ (significant proteinuria very unlikely) or $>52 \mathrm{mg} / \mathrm{mmol}$ (significant proteinuria very likely), early clinical management can be facilitated without awaiting results of 24-hour urine protein.

- When uPCR is $\geq 200 \mathrm{mg} / \mathrm{mmol}, 24$-hour urine is needed for an accurate quantification as correlation between these two tests is low above this level.

\section{Introduction}

Pre-eclampsia, or de-novo proteinuric hypertension after 20 weeks of pregnancy, ${ }^{1}$ is a major cause of maternal and perinatal morbidity and mortality due to eclampsia, cerebrovascular events, preterm delivery, and fetal growth restriction. In industrialised countries, the incidence has been reported to be $3 \%$ to $5 \%$ of pregnancies. ${ }^{2,3}$ In a territory-wide study in
China, hypertensive disorders complicated $5.2 \%$ of all pregnancies, with more than $50 \%$ of them being pre-eclampsia. ${ }^{4}$

The gold standard for diagnosis of proteinuria is the presence of $>300 \mathrm{mg}$ of protein in a 24-hour urine sample. ${ }^{1}$ This test, however, is cumbersome and time-consuming for women, has cost implications, can cause a delay in diagnosis and 


\section{先兆子痛症華籍孕婦的尿蛋白肌酤比值診斷蛋白 尿的準確度以及其與不良妊娠結局的關聯}

\section{張凱晴、梁國賢、蔡祥熙}

引言：國際準則經已認可檢測顯著蛋白尿時, 可使用單泡尿蛋白與肌 酐比值（uPCR）為每 $\mathrm{mmol} 30 \mathrm{mg}$ 以上, 來替代24小時尿液樣本。本 研究旨在確定UPCR 預測顯著蛋白尿的準確度以及其與不良妊娠結局 的關聯。

方法: 本回顧研究於香港一所分區醫院的產科部內進行。參與者為 2011 年1月至2013年12月期間在伊利沙伯醫院生產的 120 名患有先兆 子瘉症的華籍孕婦。研究參與者的 uPCR與24小時蛋白尿的關係、在 不同臨界值uPCR與24小時蛋白尿的準確度, 以及uPCR與不良妊娠結 局的關係。

結果：當uPCR低於 $200 \mathrm{mg} / \mathrm{mmol}$ 時, uPCR與24小時蛋白尿顯著相 關（Pearson相關係數 $=0.914 ; \mathrm{P}<0.0001$ ）。在華籍孕婦中, uPCR 的最佳診斷門檻 $(33 \mathrm{mg} / \mathrm{mmol})$ 與國際文獻相若 $(30 \mathrm{mg} / \mathrm{mmol})$

使用 $20 \mathrm{mg} / \mathrm{mmol}$ 的診斷門檻得出 $100 \%$ 敏感性, 而 $52 \mathrm{mg} / \mathrm{mmol}$ 的診 斷門檻則得出 $100 \%$ 特異性。uPCR結果在有否出現不良妊娠結局的情 況下均沒有顯著差異。

結論：在先兆子疡症華藉孕婦中, 如果uPCR低於 $200 \mathrm{mg} / \mathrm{mmol}$, uPCR與24小時尿蛋白的結果呈顯著正相關。然而, uPCR不能預測不 良妊娠結局。 clinically important outcomes. ${ }^{5}$

The aims of this study were to determine the accuracy of uPCR in predicting significant proteinuria in our local population, and adverse maternal or neonatal outcomes. If uPCR can accurately predict significant proteinuria and adverse pregnancy outcomes, it will be a quick, acceptable, and potentially cost-effective alternative to 24-hour urine for protein analysis. The clinical management of suspected proteinuric hypertension in pregnancy can then be modified to facilitate an early diagnosis or exclusion of pre-eclampsia.

\section{Methods}

All Chinese pregnant women with a diagnosis of pre-eclampsia (new-onset proteinuric hypertension after 20 weeks of gestation) and who delivered at Queen Elizabeth Hospital in Hong Kong from January 2011 to December 2013 (36 months) were eligible for initial inclusion in this retrospective study. Hypertension was defined as blood pressure of $\geq 140 / 90 \mathrm{~mm} \mathrm{Hg}$. Significant proteinuria was defined as 24-hour urine total protein of $\geq 300 \mathrm{mg} /$ day or uPCR of $\geq 30 \mathrm{mg} / \mathrm{mmol}$ (local laboratory reference) if the former was not available. Test of UPCR has been available for a long period and has been widely used in our department since January 2011. The diagnosis of proteinuria was mostly based on 24-hour urine testing rather than uPCR before January 2011. Women were excluded from the study if they had pre-existing renal disease, chronic hypertension, or co-existing urinary tract infection (defined by a positive mid-stream urine culture). The study was approved by the hospital research and ethics committee as a registered study (Ref.: KC/KE15-0025), with the requirement of patient informed consent waived because of its retrospective nature.

In this study, uPCR was collected as a random urine sample at any time of the day. It was collected in the presence of a positive urine dipstick for protein or in women who presented with hypertension (even dipstick negative) to confirm or exclude proteinuria. For 24-hour urine, women were provided with a bottle and instructions to collect all urine within a 24-hour period. All collections were sent to the laboratory within 1 day of completion. Urine total protein was measured using a turbidimetric method based on benzethonium chloride reaction. Urine creatinine was measured using a kinetic colorimetric assay based on the Jaffé method. Both tests were performed with a Roche/Hitachi cobas c501 analyser (cobas 6000 system; Roche Diagnostics GmbH, Mannheim, Germany). The imprecision (coefficient of variation) of the urine protein assay was $3.7 \%$ at $0.18 \mathrm{~g} / \mathrm{L}$ and $1.9 \%$ at $0.54 \mathrm{~g} / \mathrm{L}$. The imprecision of the urine creatinine assay was $6.9 \%$ at $7.0 \mathrm{mmol} / \mathrm{L}$ and $2.2 \%$ at $20.8 \mathrm{mmol} / \mathrm{L}$.

For the primary outcome analysis, women who 
had both uPCR and adequate 24-hour urine results collected within 24 hours were identified. 24-Hour urine collection was often inaccurate (due to overor under-collection), even though patients have been provided with a standard instruction. It has been reported that $13 \%$ to $54 \%$ of 24 -hour urine collections were inaccurate, with $24.8 \%$ of patients having a difference of $\geq 25 \%$ in the results between collections, exceeding the analytical and biological variation. ${ }^{14}$ Completeness of a 24-hour urine collection was assessed by urinary creatinine excretion. The normal range for urinary creatinine excretion was 7 to 14 $\mathrm{mmol} /$ day in our laboratory as recommended by the vendor of the test. Considering a mean body weight of $70 \mathrm{~kg}$ during pregnancy and understanding that urinary creatinine excretion remains unchanged in pregnancy, this reference range was compatible with general nephrology references of 133 to 177 $\mu \mathrm{mol} / \mathrm{kg} /$ day of lean body mass. ${ }^{15}$ The two urine tests should be collected within 1 day to avoid the effect of day-to-day variation on the amount of protein in urine.

For the secondary outcome analysis, adverse maternal outcomes were represented by severe hypertension (blood pressure $\geq 160 / 110 \mathrm{~mm} \mathrm{Hg}$ ), raised liver enzyme (alanine aminotransferase or aspartate aminotransferase $\geq 70 \mathrm{IU} / \mathrm{L}$ ), renal insufficiency (serum creatinine $\geq 80 \mu \mathrm{mol} / \mathrm{L}$ ), thrombocytopenia (platelet count $<100 \times 10^{9} / \mathrm{L}$ ), admission to intensive care unit (ICU), eclampsia, or maternal mortality. Adverse neonatal outcomes were represented by prematurity (delivery at $<37$ weeks' gestation), low birth weight $(<2500 \mathrm{~g})$, smallfor-gestational age based on local population data, low Apgar score $(<7)$ at 1 minute and 5 minutes of birth, admission to the neonatal intensive care unit (NICU), stillbirth, or early neonatal death. Data for maternal and neonatal outcomes were obtained from the hospital's Clinical Data Analysis and Reporting System and individual medical records. To minimise the effect of multiple pregnancy on the clinical outcome, only singleton pregnancies were included for secondary outcome analysis. If more than one sample of uPCR were collected during the pregnancy, the first uPCR at the onset of proteinuria was used to determine the association with adverse outcomes.

Data were analysed using the Statistical Package for the Social Sciences (Windows version 22.0; SPSS Inc, Chicago [IL], US). For the primary outcome analysis, the relationship between UPCR and 24-hour urine was assessed by Pearson correlation coefficient after taking logarithm as the data distribution of these two parameters were not nominal. Sensitivity, specificity, and positive and negative predictive values of uPCR were calculated. The sensitivity and specificity of uPCR at different cut-offs were analysed by receiver operating characteristics (ROC) curve. For the secondary outcome analysis, Mann-
Whitney $U$ test was used to determine the difference in proteinuria level between cases with or without an adverse pregnancy outcome.

\section{Results}

Of 432 cases of pre-eclampsia identified during the 36month study period, 175 (40.5\%) had uPCR analysed after excluding cases without collection of uPCR before delivery or ordering because of individual clinician's preference or because immediate delivery was expected. Of these 175 cases, 55 (31.4\%) were excluded after review of medical records, including 28 non-Chinese patients, 24 cases with pre-existing hypertension or pre-existing renal disease, one woman with active urinary tract infection, one with missing information, and one who did not deliver at our hospital. Urine samples collected from the remaining 120 women, who ranged from 24 weeks to 41 weeks of gestation, were analysed. The general characteristics of the study population are shown in Table 1.

\section{Spot urine protein-to-creatinine ratio and 24-hour urine protein}

Of these 120 cases, 98 pairs of urine samples were collected, of which 12 were inadequate and 20 were collected more than 1 day apart. The remaining 66 pairs with both uPCR and adequate 24-hour urine collection available within 1 day were used for the primary outcome analysis. The median body weight of these 66 women was $72.1 \mathrm{~kg}$ (range, $56.5-97.0 \mathrm{~kg}$ ).

The two tests were correlated with a Pearson correlation coefficient $(r)$ of $0.914 \quad(\mathrm{P}<0.0001)$. From Figure 1, it is clear that a positive and linear correlation between UPCR and 24-hour urine protein was evident up to a uPCR of $200 \mathrm{mg} / \mathrm{mmol}$.

TABLE I. General characteristics of the study population $(n=\mid 20)$

\begin{tabular}{|c|c|}
\hline Characteristic & Median (range) or No. (\%) \\
\hline Age (years) & $34(18-46)$ \\
\hline BMI (at the time of booking) $\left[\mathrm{kg} / \mathrm{m}^{2}\right]$ & $22.8(15.6-35.3)$ \\
\hline \multicolumn{2}{|l|}{ Parity } \\
\hline Nulliparity & $89(74.2)$ \\
\hline Multiparity & $31(25.8)$ \\
\hline \multicolumn{2}{|l|}{ Admission blood pressure (mm Hg) } \\
\hline Systolic & $150(107-232)$ \\
\hline Diastolic & $91(63-136)$ \\
\hline Gestational age at onset of proteinuria (weeks) & $35(24-40)$ \\
\hline Preterm (<37 weeks) at onset of proteinuria & $85(70.8)$ \\
\hline Gestational age at delivery (weeks) & $36(24-41)$ \\
\hline uPCR (mg/mmol) & $98.5(0.04-1112)$ \\
\hline
\end{tabular}

Abbreviations: $\mathrm{BMI}=$ body mass index; $\mathrm{uPCR}=$ spot urine protein-to-creatinine ratio 


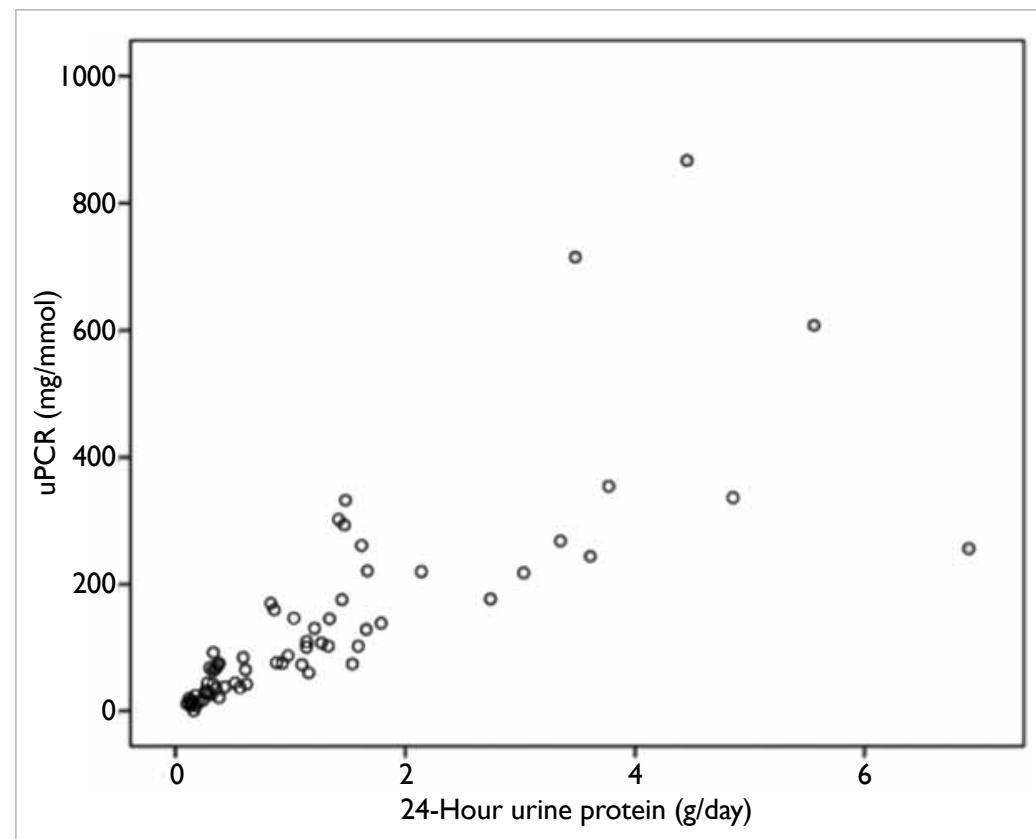

FIG I. Individual 24-hour urine protein versus spot urine protein-to-creatinine ratio (uPCR) values $(n=66)$

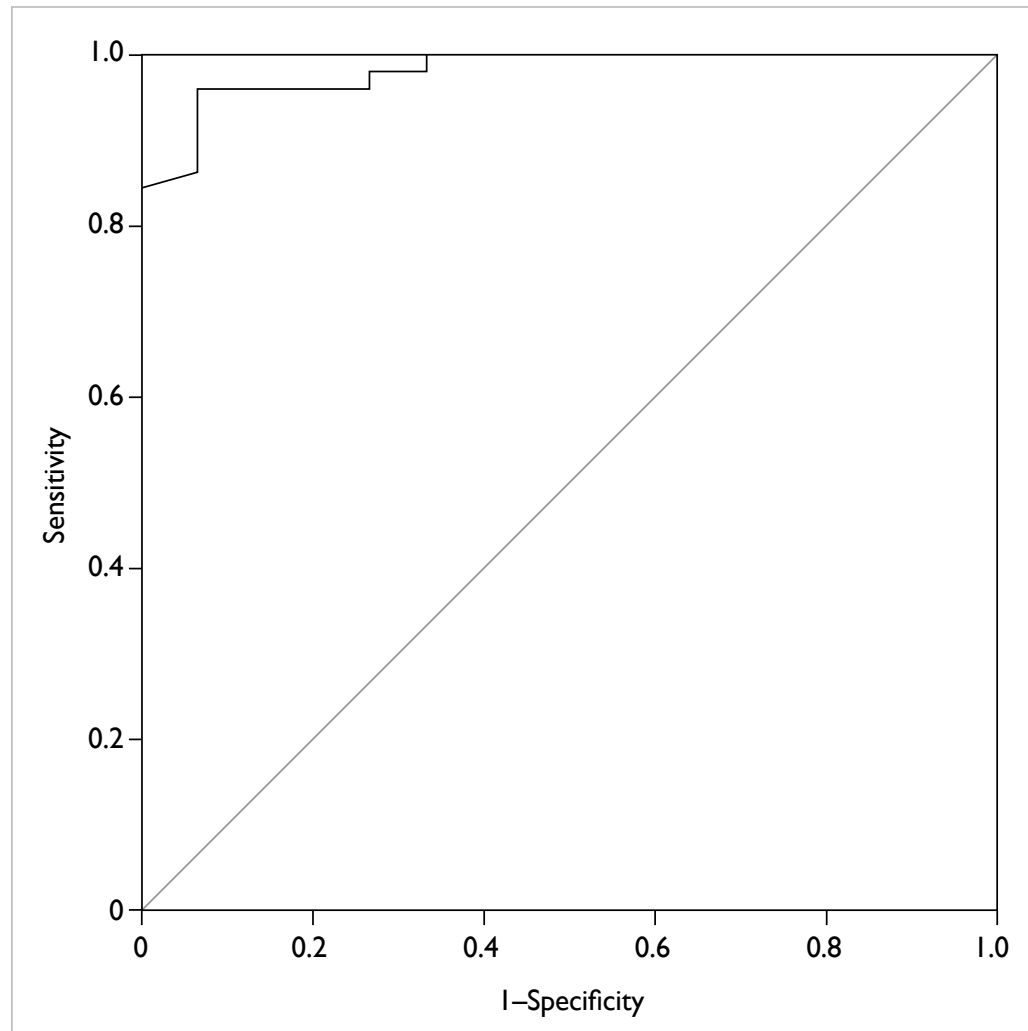

FIG 2. Receiver operator characteristics analysis $(n=66)$

Diagonal segments are produced by ties
On subgroup analysis, the correlation coefficient was high $(0.875)$ and significant $(\mathrm{P}<0.0001)$ for $\mathrm{uPCR}$ of $<200 \mathrm{mg} / \mathrm{mmol}$, but low (0.389) and non-significant ( $\mathrm{P}=0.152$ ) for $\mathrm{uPCR}$ of $\geq 200 \mathrm{mg} / \mathrm{mmol}$.

With the local laboratory reference of uPCR set at $30 \mathrm{mg} / \mathrm{mmol}$, as suggested by international guidelines, ${ }^{1,5,6}$ the positive predictive value of significant proteinuria (defined by 24-hour urine total protein $\geq 300 \mathrm{mg} /$ day) was $96 \%$, sensitivity $96 \%$, negative predictive value $87 \%$, and specificity $87 \%$. Two false-positive cases and two false-negative cases were found. For the two false-positive cases, the 24-hour urine results were $0.28 \mathrm{~g} / \mathrm{d}$ and $0.26 \mathrm{~g} / \mathrm{d}$ and corresponding uPCR results were $44 \mathrm{mg} / \mathrm{mmol}$ and $31 \mathrm{mg} / \mathrm{mmol}$. Although these 24-hour urine results were negative, these women subsequently developed proteinuria and were confirmed to have pre-eclampsia. For the two false-negative cases, their 24-hour urine results were $0.31 \mathrm{~g} / \mathrm{d}$ and $0.38 \mathrm{~g} / \mathrm{d}$ and corresponding $\mathrm{uPCR}$ results were $26 \mathrm{mg} / \mathrm{mmol}$ and $21 \mathrm{mg} / \mathrm{mmol}$.

The area under ROC curve was 0.981 (95\% confidence interval [CI], 0.954-1.000; Fig 2). The optimal threshold of uPCR for diagnosing proteinuria was $33 \mathrm{mg} / \mathrm{mmol}$. This gave the same sensitivity but a slightly higher specificity when compared with the suggested threshold of $30 \mathrm{mg} / \mathrm{mmol},{ }^{1}$ although there was a large overlap of $95 \%$ CIs (Table 2). A lower cut-off of $20 \mathrm{mg} / \mathrm{mmol}$ rather than the local laboratory reference of $30 \mathrm{mg} / \mathrm{mmol}$ on the uPCR would give $100 \%$ sensitivity. A higher cut-off of $52 \mathrm{mg} / \mathrm{mmol}$ would have $100 \%$ specificity (Table 2 ).

\section{Spot urine protein-to-creatinine ratio and adverse pregnancy outcomes}

We excluded 25 multiple pregnancies for this secondary outcome analysis. Of the remaining 95 singleton pregnancies with pre-eclampsia, the median gestation age of onset of proteinuria was 35 weeks and $64 \%$ were preterm $(<37$ weeks) at the onset.

For maternal outcome, $47 \%$ of women developed severe hypertension, 6\% developed raised liver enzymes, 6\% renal insufficiency, and $2 \%$ thrombocytopenia. Admission to the ICU was required by $16 \%$. There was no case of eclampsia or maternal mortality. Substantial differences in UPCR were observed in cases with and without raised liver enzymes and thrombocytopenia, although the differences were not statistically significant due to the small number of cases (Table 3).

For the neonatal outcome of all singleton pregnancies, $60 \%$ were born with low birth weight, $21 \%$ with low Apgar score at 1 minute, $6 \%$ with low Apgar score at 5 minutes of birth, and 54\% required admission to the NICU. There was no case of stillbirth or early neonatal death. On the other hand, UPCR was significantly greater in newborns 
who required admission to the NICU than in those low and insignificant if $\mathrm{uPCR}$ was $\geq 200 \mathrm{mg} / \mathrm{mmol}$. who did not. Nonetheless, if only women with onset This is similar to the finding of another study that of proteinuria before 34 weeks were included, there reported a lower positive predictive value between was no difference in UPCR between newborns with 24-urine protein excretion and uPCR for the greater and without neonatal complications (Table 4).

\section{Discussion}

degree of proteinuria $(>1 \mathrm{~g} /$ day $){ }^{16}$

In the present study, the optimal threshold of Consistent with previous studies, ${ }^{7,8}$ our present study This gave a similar predictive value when compared has shown a positive and significant correlation of with the suggested threshold of $30 \mathrm{mg} / \mathrm{mmol}$ (Table uPCR with 24-hour urine result. This correlation was 2). ${ }^{1}$ The area under ROC curve in the present study

TABLE 2. Comparison of accuracy of uPCR against 24-hour urine protein at different cut-offs ( $n=66$ )

\begin{tabular}{lcccc}
\hline uPCR (mg/mmol) & Sensitivity (95\% Cl) & Specificity (95\% Cl) & PPV (95\% Cl) & NPV (95\% Cl) \\
\hline 20 & $100 \%(91-100 \%)$ & $67 \%(38-87 \%)$ & $91 \%(79-96 \%)$ & $100 \%(65-100 \%)$ \\
30 & $96 \%(85-99 \%)$ & $87 \%(58-97 \%)$ & $96 \%(85-99 \%)$ & $87 \%(58-97 \%)$ \\
33 & $96 \%(85-99 \%)$ & $93 \%(66-99 \%)$ & $98 \%(87-99 \%)$ & $88 \%(60-97 \%)$ \\
52 & $84 \%(70-92 \%)$ & $100 \%(74-100 \%)$ & $100 \%(89-100 \%)$ & $65 \%(42-82 \%)$ \\
\hline
\end{tabular}

Abbreviations: $\mathrm{Cl}=$ confidence interval; $\mathrm{NPV}=$ negative predictive value; $\mathrm{PPV}=$ positive predictive value; $\mathrm{UPCR}=$ spot urine proteinto-creatinine ratio

TABLE 3. Proteinuria determined by uPCR in pre-eclamptic patients with and without adverse maternal complications ( $\mathrm{n}=95)^{*}$

\begin{tabular}{lcccc}
\hline $\begin{array}{l}\text { Adverse maternal } \\
\text { complication }\end{array}$ & & Present & & Absent \\
\hline Severe hypertension & $45(47)$ & $112.17 \pm 3.45$ & $50(53)$ & $84.77 \pm 3.35$ \\
Raised liver enzymes & $6(6)$ & $175.91 \pm 5.70$ & $89(94)$ & $92.76 \pm 3.26$ \\
Renal insufficiency & $6(6)$ & $102.51 \pm 3.09$ & $89(94)$ & $96.54 \pm 3.44$ \\
Thrombocytopenia & $2(2)$ & $492.75 \pm 3.16$ & $93(98)$ & $93.69 \pm 3.34$ \\
Admission to ICU & $15(16)$ & $78.25 \pm 3.70$ & $80(84)$ & $100.48 \pm 3.36$ \\
\hline
\end{tabular}

Abbreviations: ICU = intensive care unit; $\mathrm{UPCR}=$ spot urine protein-to-creatinine ratio

* Data were shown as No. (\%) of women or mean ( \pm standard deviation) proteinuria level $(\mathrm{mg} / \mathrm{mmol})$

+ Mann-Whitney $U$ test

TABLE 4. Proteinuria determined by uPCR in pre-eclamptic patients with and without adverse neonatal complications*

\begin{tabular}{|c|c|c|c|c|c|}
\hline Adverse neonatal complication & \multicolumn{2}{|c|}{ Present } & \multicolumn{2}{|c|}{ Absent } & $\mathbf{P}$ valuet \\
\hline \multicolumn{6}{|l|}{ All singleton pregnancies $(n=95)$} \\
\hline Low birth weight & $57(60)$ & $95.02 \pm 3.26$ & $38(40)$ & $63.31 \pm 3.31$ & 0.106 \\
\hline Low Apgar score at $1 \mathrm{~min}$ & $20(21)$ & $109.75 \pm 2.92$ & $75(79)$ & $74.43 \pm 3.39$ & 0.199 \\
\hline Low Apgar score at 5 mins & $6(6)$ & $75.24 \pm 4.58$ & $89(94)$ & $81.16 \pm 3.27$ & 0.882 \\
\hline Admission to NICU & $51(54)$ & $114.13 \pm 3.13$ & $44(46)$ & $54.11 \pm 3.16$ & 0.002 \\
\hline \multicolumn{6}{|c|}{ Singleton pregnancies with onset of proteinuria $<34$ weeks $(n=35)$} \\
\hline Prematurity & $33(94)$ & $149.90 \pm 2.69$ & $2(6)$ & $48.91 \pm 1.37$ & 0.125 \\
\hline Small-for-gestational age & $7(20)$ & $115.58 \pm 2.70$ & $28(80)$ & $146.94 \pm 2.75$ & 0.570 \\
\hline Low Apgar score at $1 \mathrm{~min}$ & $14(40)$ & $130.32 \pm 2.33$ & $21(60)$ & $148.41 \pm 3.02$ & 0.716 \\
\hline Low Apgar score at 5 mins & $4(11)$ & $104.58 \pm 2.38$ & $31(89)$ & $145.48 \pm 2.77$ & 0.543 \\
\hline Admission to NICU & $30(86)$ & $148.41 \pm 2.71$ & $5(14)$ & $101.49 \pm 2.90$ & 0.448 \\
\hline
\end{tabular}

Abbreviations: NICU = neonatal intensive care unit; uPCR = spot urine protein-to-creatinine ratio

* Data were shown as No. (\%) of women or mean ( \pm standard deviation) proteinuria level $(\mathrm{mg} / \mathrm{mmol})$

† Mann-Whitney $U$ test 
was 0.981 and was comparable with the result of a meta-analysis that included 24 trials with 3186 participants in which the area under summary ROC curve was 0.90 , with pooled sensitivities and specificities of $91 \%$ and $86.3 \%$, respectively. ${ }^{8}$

Using a cut-off of 20 and $52 \mathrm{mg} / \mathrm{mmol}$ had $100 \%$ sensitivity and $100 \%$ specificity, respectively (Table 2). Similar findings for the cut-off value were noted in a systematic review of seven studies with 1717 patients. ${ }^{17}$ Random uPCR determinations are helpful primarily when they are $<150 \mathrm{mg} / \mathrm{g}$ (17 $\mathrm{mg} / \mathrm{mmol}$ ) as $\geq 300 \mathrm{mg}$ proteinuria is unlikely to be below this threshold. Nonetheless, for uPCR $>600$ $\mathrm{mg} / \mathrm{g}(67.8 \mathrm{mg} / \mathrm{mmol})$, significant proteinuria could be established.

In clinical practice, there are three scenarios. First, if uPCR is $>52 \mathrm{mg} / \mathrm{mmol}$ ( $66 \%$ of cases in the present study), significant proteinuria will be highly likely and the positive predictive value of a composite adverse neonatal outcome will be high $(78.7 \%$ in the present study). Second, if uPCR is $<20 \mathrm{mg} / \mathrm{mmol}$ ( $13 \%$ in the present study), significant proteinuria will be very unlikely. In either scenario, an earlier clinical decision can be made without ordering or completion of 24-hour urine collection or awaiting results. 24-Hour urine collection can be omitted in the majority of cases, therefore shortening the time to diagnose or exclude pre-eclampsia. Third, if uPCR is 20 to $52 \mathrm{mg} / \mathrm{mmol}$ ( $21 \%$ in the present study), 24-hour urine results will be required to confirm or exclude significant proteinuria. Although 24-hour urinary protein of $\geq 300 \mathrm{mg} /$ day is the gold standard for diagnosing abnormal proteinuria in pregnancy, this is more a time-honoured value than one with high scientific proof. ${ }^{1}$ Having said that, in cases of gestational hypertension with proteinuria of $<300$ $\mathrm{mg} /$ day, attention should still be warranted if the uPCR is $>30 \mathrm{mg} / \mathrm{mmol}$, particularly if it shows a rising trend.

If $\mathrm{uPCR}$ is $\geq 200 \mathrm{mg} / \mathrm{mmol}$, correlation with 24-hour urine analysis will be low. In such cases, proteinuria should be confirmed with 24-hour urine protein measurement. It is probable that nephrotic range proteinuria exists above this threshold, thus necessitating prophylaxis against thromboembolism. ${ }^{1}$

It is controversial whether $\mathrm{UPCR}$ can predict clinical outcome. Some studies ${ }^{10-12}$ have suggested that proteinuria is related to adverse pregnancy outcomes, for example, severe hypertension, renal insufficiency, liver disease, preterm delivery, small-for-gestational age, and transfer to NICU. Nonetheless, the latest ISSHP (International Society for the Study of Hypertension in Pregnancy) guideline suggests that the degree of proteinuria provides very little additional risk stratification in cases of preeclampsia, and does not include it when defining the severity of the disease. ${ }^{1}$ The recent multicentre
PIERS (Pre-eclampsia Integrated Estimate of Risk) study demonstrated that neither uPCR nor 24-hour urine protein output was predictive of adverse perinatal outcome and hence concluded that the amount of proteinuria should not be used in isolation for decision making in women with pre-eclampsia. ${ }^{13}$ In the present study that focused on Chinese preeclamptic women, uPCR was significantly greater in cases that required admission to the NICU. This difference was no longer evident if only cases with early-onset proteinuria were included in the analysis. This shows that the observed difference in $\mathrm{UPCR}$ was related to the management strategy of preterm delivery in cases with early-onset pre-eclampsia rather than to the severity of proteinuria itself.

The study provides an insight into the accuracy of $\mathrm{UPCR}$ and its relationship with pregnancy outcomes in a local Chinese population. Nonetheless, the present study was small and retrospective. Only those with a valid spot urine sample were included in the study and women with severe pre-eclampsia who required immediate treatment and delivery were excluded. The results would therefore be affected by such selection bias. The precision of the ROC curve is limited by the small sample size. Further research by a prospective study with timed urine collection and larger sample size is suggested to validate the findings of the present study.

\section{Conclusions}

There was a positive and significant correlation of uPCR with 24-hour urine protein result in Chinese pre-eclamptic women when uPCR was $<200$ $\mathrm{mg} / \mathrm{mmol}$. Significant proteinuria can probably be excluded in the presence of uPCR of $<20 \mathrm{mg} / \mathrm{mmol}$, but it should be considered when uPCR $>52 \mathrm{mg} / \mathrm{mmol}$. Significant proteinuria should be confirmed by 24-hour urine collection when uPCR is 20 to $52 \mathrm{mg} /$ mmol, and uPCR was not significant in predicting adverse pregnancy outcomes.

\section{Acknowledgements}

The authors would like to thank Dr CC Shek from the Department of Pathology of Queen Elizabeth Hospital for his valuable assistance for providing information on the laboratory tests. We would also like to thank Ms Janice Yung for her kind clerical assistance in the preparation of this manuscript.

\section{Declaration}

All authors have disclosed no conflicts of interest.

\section{References}

1. Tranquilli AL, Dekker G, Magee L, et al. The classification, diagnosis and management of the hypertensive disorders of pregnancy: A revised statement from the ISSHP. 
Pregnancy Hypertens 2014;4:97-104.

2. Hutcheon JA, Lisonkova S, Joseph KS. Epidemiology of pre-eclampsia and the other hypertensive disorders of pregnancy. Best Pract Res Clin Obstet Gynaecol 2011;25:391-403.

3. Tan KH, Kwek K, Yeo GS. Epidemiology of pre-eclampsia and eclampsia at the KK Women's and Children's Hospital, Singapore. Singapore Med J 2006;47:48-53.

4. Ye C, Ruan Y, Zou L, et al. The 2011 survey on hypertensive disorders of pregnancy (HDP) in China: prevalence, risk factors, complications, pregnancy and perinatal outcomes. PLoS One 2014;9:e100180.

5. Hypertension in pregnancy: the management of hypertensive disorders during pregnancy. NICE Clinical Guidelines, No. 107. London: RCOG Press; 2010.

6. Lowe SA, Bowyer L, Lust K, et al. SOMANZ guidelines for the management of hypertensive disorders of pregnancy 2014. Aust NZJ Obstet Gynaecol 2015;55:e1-e29.

7. Morris RK, Riley RD, Doug M, Deeks JJ, Kilby MD. Diagnostic accuracy of spot urinary protein and albumin to creatinine ratios for detection of significant proteinuria or adverse pregnancy outcome in patients with suspected pre-eclampsia: systematic review and meta-analysis. BMJ 2012;345:e4342.

8. Sanchez-Ramos L, Gillen G, Zamora J, Stenyakina A, Kaunitz AM. The protein-to-creatinine ratio for the prediction of significant proteinuria in patients at risk for preeclampsia: a meta-analysis. Ann Clin Lab Sci 2013;43:211-20

9. James GD, Sealey JE, Alderman M, et al. A longitudinal study of urinary creatinine and creatinine clearance in normal subjects. Race, sex, and age differences. Am J Hypertens 1988;1:124-31.

10. Chan P, Brown M, Simpson JM, Davis G. Proteinuria in pre-eclampsia: how much matters? BJOG 2005;112:2805.

11. Thornton CE, Makris A, Ogle RF, Tooher JM, Hennessy A. Role of proteinuria in defining pre-eclampsia: clinical outcomes for women and babies. Clin Exp Pharmacol Physiol 2010;37:466-70.

12. Bouzari Z, Javadiankutenai M, Darzi A, Barat S. Does proteinuria in preeclampsia have enough value to predict pregnancy outcome? Clin Exp Obstet Gynecol 2014;41:163-8.

13. Payne B, Magee LA, Côté AM, et al. PIERS proteinuria: relationship with adverse maternal and perinatal outcome. J Obstet Gynaecol Can 2011;33:588-97.

14. Côté AM, Firoz T, Mattman A, Lam EM, von Dadelszen P, Magee LA. The 24-hour urine collection: gold standard or historical practice? Am J Obstet Gynecol 2008;199:625. e1-6.

15. Perrone RD, Madias NE, Levey AS. Serum creatinine as an index of renal function: new insights into old concepts. Clin Chem 1992;38:1933-53.

16. Demirci O, Kumru P, Arınkan A, et al. Spot protein/ creatinine ratio in preeclampsia as an alternative for 24-hour urine protein. Balkan Med J 2015;32:51-5.

17. Papanna R, Mann LK, Kouides RW, Glantz JC. Protein/ creatinine ratio in preeclampsia: a systematic review. Obstet Gynecol 2008;112:135-44. 